\title{
Correction to: Bioeconomy imaginaries: A review of forest-related social science literature
}

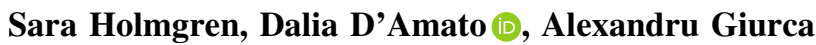

Published online: 23 February 2022

\section{Correction to: Ambio (2020) 49:1860-1877 \\ https://doi.org/10.1007/s13280-020-01398-6}

In the original publication, the grant number 2016-00857 was missed mistakenly in the acknowledgements section. Below is the correct acknowledgements of the article.

Acknowledgements Open access funding provided by University of Helsinki including Helsinki University Central Hospital. This study was funded through the Swedish Research Council for Sustainable Development (FORMAS) (Reg. No. 942-2016-30, 2016-00857), Academy of Finland (projects OPES, funding decision no. 315912), and European Forest Institute (EFI) through its EFI Network Fund initiative. The publication is part of the PerForm project, a collaboration network of social scientists from across Europe, investigating societal perceptions of the forest-based bioeconomy.

The original article has been corrected.

Open Access This article is licensed under a Creative Commons Attribution 4.0 International License, which permits use, sharing, adaptation, distribution and reproduction in any medium or format, as long as you give appropriate credit to the original author(s) and the source, provide a link to the Creative Commons licence, and indicate if changes were made. The images or other third party material in this article are included in the article's Creative Commons licence, unless indicated otherwise in a credit line to the material. If material is not included in the article's Creative Commons licence and your intended use is not permitted by statutory regulation or exceeds the permitted use, you will need to obtain permission directly from the copyright holder. To view a copy of this licence, visit http://creativecommons. org/licenses/by/4.0/.

Publisher's Note Springer Nature remains neutral with regard to jurisdictional claims in published maps and institutional affiliations.

\section{Sara Holmgren}

Address: Department of Urban and Rural Development, Swedish University of Agricultural Sciences, Ulls väg 27, 75007 Uppsala, Sweden.

e-mail: sara.holmgren@slu.se

Dalia D’Amato $(\square)$

Address: Helsinki Institute of Sustainability Science, Department of Forest Sciences, Faculty of Agriculture and Forestry, University of Helsinki, Latokartanonkaari 7, P.O. Box 27, 00014 Helsinki, Finland. e-mail: dalia.damato@helsinki.fi

\section{Alexandru Giurca}

Address: Chair of Forest and Environmental Policy, Faculty of Environment and Natural Resources, University of Freiburg, Tennenbacherstr. 4, 79106 Freiburg, Germany.

e-mail: alex.giurca@ifp.uni-freiburg.de

The original article can be found online at https://doi.org/10.1007/ s13280-020-01398-6. 